\title{
Consumer Behaviour and Attitude Towards the Role of Businesses' Corporate Social Responsibility in Circular Economy Development: Casestudy of Domestic Tourism in Vietnam
}

\author{
Nguyen Quynh HOA* \\ Department of Business Administration, School of Economics and Management, \\ Hanoi University of Science and Technology, Hanoi, Vietnam \\ *Corresponding Author: hoa.nguyenquynh@hust.edu.vn
}

\begin{abstract}
Tourism literature worldwide has been studying about its negative impacts on tourist destinations and local communities. Besides its contribution to the economic development, many researchers have warned about some unwanted footprints left from the tourists that would give a significant pressure on the environment, such as: pollution, loss of biodiversity, natural heritage damage, etc. Recently, researchers have started to talk about the concept of circular economy (CE) which goes along with the United Nations' sustainable development goals (SDGs) and attaches well with the corporate social responsibility (CSR) activities.
\end{abstract}

\section{Research purpose:}

The purpose of this study is to identify how this concept would be applied into the tourism industry under the tourists' view.

Research motivation:

As tourists is one of the key stakeholders to implement the tourism sustainability concept into real practice, understand their attitude and behaviours towards CSR activities and its contribution to the CE would bring some ideas to the planning and management process of local governments and tourism businesses.

Research design, approach, and method:

The study is conducted in two phases: (1) a pilot survey in Hanoi from 15 to 30 May 2021 to facilitate the generation of measurement items of the tourists' attitude and behaviours, and (2) a structured survey on 316 domestic customers from 30 cities and provinces in Vietnam from 15 to 30 June 2021 by both face-to-face and online methods.

\section{Main findings:}

It is found that domestic customers in this study are aware of the benefits of CSR activities in sustainable tourism, especially in environment practices. They try to save natural resources (energy, water, etc.), use renewable energy sources if available, consume organic and environmentally friendly products, reduce using plastic, use recycle products, and do more recycling. They believe that CSR would be a long-term strategy of tourism businesses to enhance their brand image and competitive advantages. Vietnamese customers are willing to cooperate with tourism businesses in CSR activities. However, young tourists seem show less confidence in the contribution of CSR into CE development and sustainability than senior people. This finding is reverse to some previous studies in other countries.

\section{Practical/managerial implications:}

This study suggests the local governments and tourism businesses in Vietnamese tourism destinations should pay more attention on educate young Vietnamese customers during their visits about the benefits of CSR and customer's cooperation in CSR activities and encourage them to co-create more values to the local communities.

Keywords: circular economy, corporate social responsibility, domestic tourist, sustainable tourism development. 


\section{INTRODUCTION}

Tourism industries have been worried about sustainability since it may bring negative effects to the environment, local communities, local society, and nature (Alonso-Almeida et. al., 2012; Girard \& Nocca, 2017; Manniche et. al., 2017; UNWTO, 2008), besides the economic impacts. Some main negative impacts have been named in previous studies, such as: (1) the high use of water, energy, (2) the production of solid and water waste, (3) the increasing transportation' carbon dioxide emissions, (4) noise and visual pollution, and (5) natural over-exploitation.

The circular economy (CE) is considered as a key solution to reduce the above-mentioned negative impacts. It is an economic system that associates well with the concept of Re-using, Re-cycling, and Recovering materials in production, distribution, and consumption. From these concepts, the CE contributes highly to the sustainable development, creates environmental quality, economic wealth, and social equity, and retain the natural resources to the future generations. Under this principle, nothing is wasted, and all the resources can be recycled to a new life and maximize their contribution. Therefore, recently, some studies have started to discuss circular tourism. Girard \& Nocca (2017) emphasized that the circular tourism would be a model which is able to create virtuous circle producing goals and services without wasting the limited resources of the planet, such as: raw materials, water, and energy.

In fact, $\mathrm{CE}$ activities have always been attached with corporate social responsibility (CSR) activities (VargasSánchez, 2018). For that reason, it is necessary to conduct more studies on how business in tourism and tourism-related areas adopt the CE concept into their CSR action plans and what challenges and barriers that they are facing. Their CE and CSR plans would not be successful without the agreement and cooperation of their customers. According to Zorpas et. al. (2021), the global amount of solid waste generated by tourism businesses in approximately more than 35 million tons per year. And tourists could produce the amount of solid waste two time more than which was from the local people. Transport-related emissions from tourism are expected to account for $5.3 \%$ of all human-made carbon dioxide gases by 2030 (Schumann, 2020). These tourism footprints contribute to climate changes (Hall, 2009; Hall \& Saarinen, 2020). Therefore, reducing the volume of waste and pollution generated by the tourism industry is a requirement that need the cooperation from all stakeholders: local government, public, businesses and tourists. However, previous studies in tourism sustainable development mainly focused on the role of government and local communities and their participation in the decision-making process. The attitude and behaviours of the customers on this issue have not yet been well investigated. Therefore, the aims of this study are to identify some insights to answer the following questions:

(1) How do the tourists evaluate the importance of tourism businesses' CSR activities to circular economy development?

(2) How are the tourists willing to cooperate with tourism businesses' CSR activities?

(3) Is there any difference in the attitude and behaviours among different groups of tourists?

Due to the situation of COVID19, this study focused on domestic tourism in Vietnam as international travelling is not yet suitable and Vietnam tourism industry may mainly rely on domestic tourists in the next few years.

\section{LITERATURE REVIEW}

\subsection{Circular economy and tourism industry}

A circular economy strategy goes along with the United Nations' sustainable development goals (SDGs) that contribute to environment conservation by tackling waste as a resource on a global scale. And through these activities, it helps to save the natural resources and reduce the cost of manufacturing. In the tourism industry, the idea of how to boost the circular business models would be a necessary plan to improve environmental performance, retain natural heritage and resources, save cost, and create new local jobs. This plan should be based on the Environmental Management Systems (EMS) principles and the "R" strategy (reused, remanufacture, recycle, redesign, and recover). To adopt this strategy well in the tourism business practice, it is in the need of training and inspiration to employees and customers. Besides, the involvement of other stakeholders is also necessary to ensure the strategy is applied across the entire tourism chain. The local government should play a key role in policy making and promoting the CE ideas and implementation, such as tax breaks, reduction of administration fees, extension of permits validity, reduction of financial guarantees, funding supports, etc., to the businesses that adopt their CSR activities to contribute to the CE (Zorpas et. al., 2021).

On the other hand, the CE strategy would help tourism businesses to enhance their environmental performance, reduce resource consumption and therefore, earn more profit, besides upgrading their destination's attraction. Economic growth is highly connected with tourism industry, especially in coastal areas like Vietnam. 


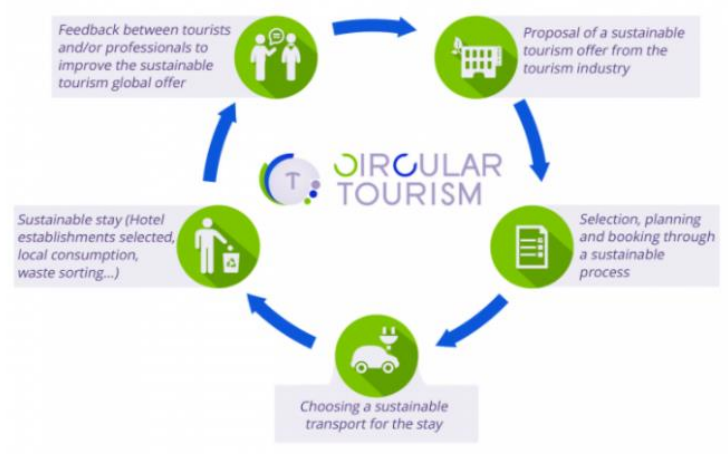

Fig. 1: Circular tourism model (Oreve, 2015)

However, there is a significant pressure on the environment from tourism activities, such as: pollution, loss of biodiversity, natural heritage damage, etc. In many destinations, the over-tourism clearly set out some challenges to the local government not only on the ecosystems, but also on the local community (Winter et. al., 2008; Adongo et. al., 2017). Scheyvens (2002) pointed out that many developing countries had become the victims of poorly planned tourism development and policies. To adopt a CE strategy, new international and national standards should be developed, and promoted to the public and tourism organizations (Von Wirth et. al., 2018). Some models of applying circular tourism standards have been introduced recently, such as ISO 14001, EMAS, Eco-label, Green-Key, etc. These standards require behavioural changes and public participation, especially the role of the tourists. Tourists in $\mathrm{CE}$ should act beyond the traditional role to encourage other people to contribute to the CE development (Reisinger, 2013; Jensen \& Prebensen, 2015; Gossling, 2018). According to Oreve (2015), the roles of tourists in circular tourism model are inclusive of (1) their awareness of sustainable tourism activities from industry professionals, (2) Their choices and behaviours to stay in a sustainable way, (3) Their choices of a soft transport to reach a destination, (4) Their responsibilities to select an sustainable institution, to consume eco-products, and to adopt eco-actions, and (5) Feedback between tourists and/ or tourism professionals to enhance sustainable tourism offers. CE strategy would be the key solution for tourism recovery and development post COVID-19 as CE has been defined as a systemic approach to economic development designed to benefit businesses, society, and environment (Ellen MacArthur Foundation, 2021).

\subsection{Corporate social responsibility in tourism and its contribution to the circular economy}

As mentioned above, a circular economy strategy goes along with the United Nations' sustainable development goals (SDGs). In tourism industry, social responsibilities are key solutions to achieve these SGDs ( $\mathrm{Su}$ et. al.,
2016; Su \& Swanson, 2017). Corporate social responsibility (CSR) refers to "context-specific organizational actions and policies that take into account stakeholders' expectations and the triple bottom line of economic, social, and environmental performance" (Aguinis, 2011, p. 855).

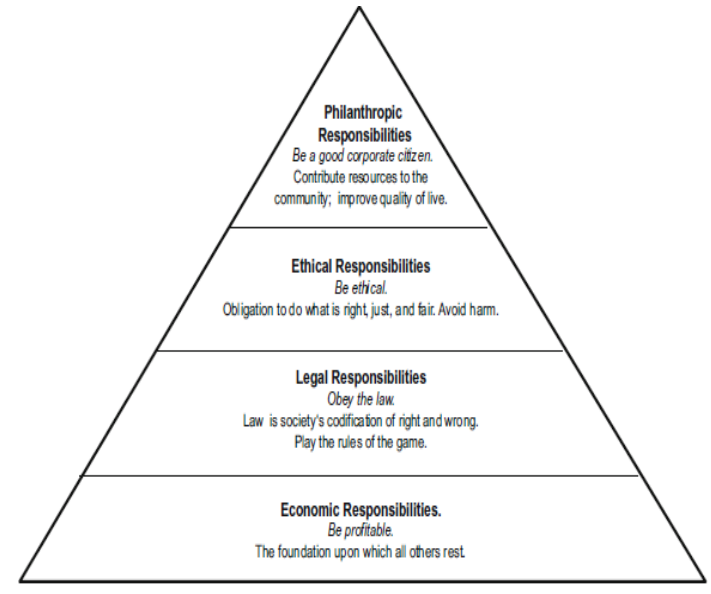

Fig. 2: The pyramid of CSR (Caroll, 1991, p.42)

Researchers in tourism literature have found the relationship between CSR and customer loyalty, customer satisfaction and port-recovery satisfaction, repurchase intentions, word-of-mouth recommendation intentions, and tourist environmentally responsible behaviours (Luu et. al., 2019; Su et. al., 2015; Su \& Swanson, 2017). Other studies have identified CSR activities in tourism context that allied well with the definition of CE and the UN's SDGs:

Table 1: CSR's focus in tourism industry literature

\begin{tabular}{|c|c|}
\hline Research & $\begin{array}{l}\text { CSR's focus in tourism } \\
\text { context }\end{array}$ \\
\hline $\begin{array}{l}\text { Bohdanowicz \& } \\
\text { Zientara (2009), } \\
\text { Font et. al. (2012) }\end{array}$ & $\begin{array}{l}\text { Improving the environment, the } \\
\text { quality of life of local } \\
\text { communities or the welfare } \\
\text { of their employees }\end{array}$ \\
\hline $\begin{array}{l}\text { Ayuso (2006), } \\
\text { Bohdanowicz \& } \\
\text { Zientara (2009), } \\
\text { Kasim }(2007)\end{array}$ & $\begin{array}{l}\text { Cost reduction and resource } \\
\text { consumption }\end{array}$ \\
\hline $\begin{array}{l}\text { Holcomb, } \\
\text { Upchurch, } \\
\text { Okumus } \quad \text { (2007), } \\
\text { Karani \& } \begin{array}{l}\text { Day } \\
(2011)\end{array}\end{array}$ & $\begin{array}{l}\text { Environmental management, } \\
\text { community dialogue and } \\
\text { employee relationships }\end{array}$ \\
\hline $\begin{array}{l}\text { Rodriguez \& Yaiza } \\
\text { (2007), Raub \& } \\
\text { Blunsch (2013), } \\
\text { Rhou et al. (2016), } \\
\text { Han et. al. (2020) }\end{array}$ & $\begin{array}{l}\text { Environmental protection, } \\
\text { corporate value, financial } \\
\text { performance, discretionary } \\
\text { work behaviors, innovation, and } \\
\text { competitiveness }\end{array}$ \\
\hline Tamajon \& Font & Energy \\
\hline
\end{tabular}




\begin{tabular}{|l|l|}
\hline (2013) & $\begin{array}{l}\text { resources recycling, encourage } \\
\text { customers to be environment- } \\
\text { friendly } \\
\text { Promote local community's } \\
\text { values, gender equality, work- } \\
\text { life balance encourage } \\
\text { customers to contribute to the } \\
\text { local community } \\
\text { Create more jobs for local } \\
\text { people improve staff salary, } \\
\text { encourage customers to } \\
\text { consume more local products, } \\
\text { more training for staff }\end{array}$ \\
\hline
\end{tabular}

\subsection{Tourists' attitude and behaviours towards tourism businesses' CSR}

According to Byrd et. al. (2009), stakeholders play a primary role in the process of sustainable development of a tourism destination. A stakeholder is any group or individual who can impact, or is impacted by, the achievement of a corporation's purpose (Freeman, 1984). The stakeholder theory of Freeman (1984) indicates that various individuals and groups could support and influence the organization and could be supported and impacted by it. In tourism context, four main stakeholder groups in a tourism destination are: (1) residents, (2) tourism businesses, (3) local government, and (4) tourists (Byrd et. al., 2009, Goeldner \& Richie, 2003). To identify the relationship between corporate social responsibilities and sustainable development, many previous studied focused on the role of local government and residents and identified the residents' attitudes and behaviours towards tourism sustainable development (Gursoy et. Al., 2002; Su et. al., 2016; Byrd et. al., 2009, Nunkoo et. al., 2010), while the tourists' significance and contribution to sustainable tourism are often neglected in the literature (Stanford, 2008). However, according to a recent study of Zorpas et. al. (2021), tourists could produce the amount of solid waste two time more than which was from the local people. Kornilaki \& Font (2019) also recognizes tourists as an important destination stakeholder who mainly impact sustainable tourism. Therefore, understand the tourists' attitudes and behaviours would bring insights into the tourism sustainability literature, especially under the CE circumstance after COVID-19.

Tourism businesses that adopt CSR activities would emphasize the increasing concerns of other stakeholders regarding sustainable development (El-Kassar \& Singh, 2019; Su \& Swanson, 2017). Su et. al. (2018) indicates that CSR activities minimize the stakeholders' negative impacts on the local environment and generate more economic, social, and environmental benefits for the local community. Tourists' social responsibility behaviours connect closely with their knowledge, experience, and perceptions. Tourists' social responsibility to a destination relates to tourism businesses' CSR responsibility activities on (1) environment, (2) socio-culture, and (3) economy (Lee et. al., 2021; Fatma et. al., 2016; Yu \& Hwang, 2019). Tourists' attitude and behaviours towards CSR activities relate closely with their satisfaction (Tran et. al., 2018), destination image and loyalty (Yu \& Hwang, 2019), tourists' citizenship behaviours (Tuan, 2017), and environmentally responsible behaviours (Xu et. al., 2019). Prebensen, Vitterso, \& Dahl (2013) confirmed that customers can co-create value through interactions with tourism businesses, therefore, their attitude and behaviours with tourism businesses' CSR activities would contribute to the success of CE development through their fulfilment of their roles and obligations in the transaction with the organizations and staff, or through their extra contributions to the society (Yi \& Gong, 2013). Besides, as tourists are main revenue resource for tourism organizations, empowerment from them could be considered as an important source for employee performance. Customers' cooperation in CSR activities would motivate the employees to be more confident to continue their tasks (Dong et. al., 2019). Chafe \& Honey (2005) imply that customers are increasingly looking for companies that engage in socially responsible activities: environmental protection, careful use of natural resources, security issues, protection of human rights, social justice, and fair working conditions. However, customers are not only pay attention to the CSR activities, but also require a business to achieve its goals and express the values. If a company succeeds in these two jobs well, the CSR can be considered as their competitive advantage (BeckerOlsen et. al., 2006)

However, most of previous studies in tourism literature have focused on the impacts of CSR on customer citizenship behaviours such as customer brand loyalty (Cha, Yi, \& Bagozzi, 2016; Martínez \& del Bosque, 2013; Su, Huang, van der Veen, \& Chen, 2014), repurchase and word-of-mouth intentions (Albus \& Ro, 2017; Ham \& Han, 2013; Prud'homme \& Raymond, 2013; Su et al., 2014; 2015), or customer environmental behavior (Luu, 2018; Su \& Swanson, 2017) rather than examining the participation and behaviours in customer value co-creation. This study explored the attitude and behaviours of the customers when they are involved in the CSR activities of tourism businesses during their travelling would bridge this gap in tourism management literature. 


\section{RESEARCH METHODOLOGY}

\subsection{Study design}

The study was conducted in two phases. In phase one, a pilot survey on 110 students and people in Hanoi was conduct from 15 May to 30 May 2021 in order to facilitate the generation of measurement items of the dimensions of tourists' attitude and behaviours towards the contribution of CSR activities in CE development. Phase two involved the development and administration of a structures survey distributed to 313 domestic tourists in some provinces and cities in Vietnam.

\subsection{Scale development}

The methodology and attributes of the research are adopted from previous literature. Some experts and peer reviewers from background of marketing, environment management, and tourism research were invited to assess the content validity of the initial 49 items generated. Then after, 13 items were withdrawn and a pilot survey was developed with 36 items which were modified to suit with the Vietnamese domestic tourism context and to fit with the research questions. Phase one consisted of 110 students who were living in Hanoi and had some experience as a domestic tourist within one to two years lately. An exploratory factor analysis was run using the Principal Components Extraction Method with Varimax rotation for the data set. Finally, 3 items were removed and the retained 33 items for the tourists' attitude and behaviours towards the importance of CSR activities to the $\mathrm{CE}$ development of a tourism destination were used and categorized into three groups: (1) environmental practice, (2) social practice, and (3) economic practice.

In phase two, data were collected from 15 June to 30 June 2021. A total of 316 individuals were approached by simple random method. Volunteers in different Vietnamese provinces and cities were hired to conduct the survey by randomly inviting respondents to complete an online questionnaire using smartphones or laptops. However, during the implementation of the survey, there was a raise of the COVID19 pandemic in some provinces in the Central and the South of Vietnam so that the volunteers in these places could only approach the respondents through an online link on some social media networks. The volunteers were trained and supervised to explain the questions and maintain the quality of data collected. The questionnaire was using a 7-point rating Likert scale where " $1=$ strongly disagree, $4=$ neutral, and $7=$ strongly agree" to quantify the responses to the items. The respondents were asked to share their attitude and behaviours based on their ideas and experience during their travelling to a tourism destination in Vietnam lately on how they evaluate the importance of tourism and/or tourism-related (hotels restaurants, travelling agencies, stations, transports, souvenir shops, entertainment parks, etc.) businesses' CSR activities to the $\mathrm{CE}$ development. Besides, questions about the participants' profile (place of living, age, job, education) were asked to explore whether these dimensions would affect their attitude and behaviours. In the end, 305 valid responses were chosen for data analysis. It is believed that all respondents answered the questionnaire honestly as it was anonymous.

\section{RESEARCH RESULTS AND DISCUSSION}

\subsection{Descriptive statistic}

Regarding to the participants' profile, they are from 30 cities and provinces of Vietnam. However, for statistic purpose, they are divided into 7 main regions according to the Vietnam administration map:

(1) Northern mountainous and midland region (Son La, Dien Bien, Lao Cai, Phu Tho, Thai Nguyen, Lang Son, Ha Giang)

(2) Red River Delta and Northeast coastal region (Hanoi, Vinh Phuc, Bac Ninh, Bac Giang, Hung Yen, Ninh Binh, Hai Phong, Quang Ninh)

(3) North Central region (Thanh Hoa, Nghe An, Ha Tinh, Quang Binh, Quang Tri, Hue)

(4) North Central coastal region (Quang Nam, Da Nang, Quang Ngai, Binh Dinh, Phu Yen, Khanh Hoa, Ninh Thuan, Binh Thuan, Vung Tau)

(5) Highland region (Kon Tum, Gia Lai, Dak Lak, Dak Nong, Lam Dong

(6) Southeast region (Ho Chi Minh city, Dong Nai, Binh Duong, Ba Ria-Vung Tau, Binh Phuoc, Tay Ninh)

(7) Mekong Delta region (Long An, Dong Thap, An Giang, Kien Giang, Ca Mau, Bac Lieu, Soc Trang, Ben Tre, Tra Vinh, Vinh Long, Tien Giang, Hau Giang, Can Tho)

Most of the respondents $(78.7 \%)$ are in region 2 which is the main part of the Northern Vietnam with largest area and highest population. The respondents from other parts are less than $10 \%$ as the result of the constrain of COVID19, they were recruited through an online link (Table 2).

Table 2: Provision of regions

\begin{tabular}{|r|r|r|}
\hline Region & Frequency & \% \\
\hline 1 & 4 & 1.3 \\
\hline 2 & 240 & 78.7 \\
\hline 3 & 24 & 7.9 \\
\hline 4 & 3 & 1.0 \\
\hline 5 & 20 & 6.6 \\
\hline 6 & 13 & 4.3 \\
\hline 7 & 1 & 0.3 \\
\hline Total & 305 & 100 \\
\hline
\end{tabular}

About half (48.9\%) of the respondents work in tourism area or related to tourism and travelling. And $51.1 \%$ of them are working in non-tourism related areas.

Most of the respondents are young tourists with $39.7 \%$ are under 25 years of age and $21.3 \%$ are from 26 to 35 years of age. About a quarter of the respondents are at the middle age (from 36 to 45 years of age), and $8.9 \%$ 
are from 46 to 55 years of age while senior travellers (over 55 years old) account for 5.2\%.

The purpose of dividing the respondents into each group as above is to explore whether these factors have influences on their awareness, attitude and behaviours towards CSR activities and CE development to the local community during their travelling.

\subsection{Customers' attitude and behaviours toward the role of tourism businesses' CSR in CE development}

According to previous studies mentioned in the Literature Review, CSR activities would contribute to the CE development in three main areas: (1) environment, (2) society, and (3) economic. In table 3, the respondents were asked to express their ideas of how importance these following CSR activities would be to a destination's environment that tourism/ tourism-related businesses in Vietnam should implement into their management and operations.

Table 3: The importance of CSR activities to a destination's environmental practices

\begin{tabular}{|l|c|c|}
\hline \multicolumn{1}{|c|}{$\begin{array}{c}\text { Environmental practices } \\
\text { (Cronbach's Alpha=0.903) }\end{array}$} & Mean & S.D \\
\hline $\begin{array}{l}\text { EP1- Energy and water saving } \\
\text { activities }\end{array}$ & 6.13 & 1.009 \\
\hline $\begin{array}{l}\text { EP2- Renewable energy sources } \\
\text { (solar, wind, biomass...) }\end{array}$ & 5.91 & 1.057 \\
\hline EP3- Waste recycling & 6.17 & 1.064 \\
\hline $\begin{array}{l}\text { EP4- Use environmentally friendly } \\
\text { products }\end{array}$ & 6.23 & 0.945 \\
\hline $\begin{array}{l}\text { EP5- Choose environmentally } \\
\text { friendly suppliers }\end{array}$ & 5.98 & 1.040 \\
\hline $\begin{array}{l}\text { EP6- Encourage customers to save } \\
\text { water and/or energy }\end{array}$ & 6.09 & 0.976 \\
\hline $\begin{array}{l}\text { EP7- Encourage customers to reduce } \\
\text { using plastic and making garbage }\end{array}$ & 6.54 & 0.769 \\
\hline $\begin{array}{l}\text { EP8 - Encourage customers to use } \\
\text { recycle products }\end{array}$ & 6.21 & 0.950 \\
\hline $\begin{array}{l}\text { EP9 - Encourage customers to use } \\
\text { organic products }\end{array}$ & 6.14 & 0.942 \\
\hline $\begin{array}{l}\text { EP10- Encourage customers to } \\
\text { participate in protection initiatives }\end{array}$ & 5.56 & 1.248 \\
\hline $\begin{array}{l}\text { EP11- Encourage customers to be } \\
\text { environmentally friendly in the } \\
\text { property }\end{array}$ & 6.38 & 0.956 \\
\hline $\begin{array}{l}\text { EP12- Encourage customers to say } \\
\text { 'No" with products from wild } \\
\text { animals or protective plant }\end{array}$ & 6.34 & 1.024 \\
\hline $\begin{array}{l}\text { EP13- Carries out actions that } \\
\text { contribute to environmental } \\
\text { conservation }\end{array}$ & 6.24 & 0.973 \\
\hline $\begin{array}{l}\text { EP14- Evaluates the environmental } \\
\text { impact of the business's CSR }\end{array}$ & 6.08 & 0.975 \\
\hline
\end{tabular}

It is clearly to see from the Table 3 that respondents are highly concerned about the impacts of tourism activities to the environment. The variables in this category all got mean scores above the neutral point of 4 . The mean scores range from minimum of 5.56 (EP10) to the maximum of 6.54 (EP7). These results imply that the customers are aware of their role in participation in protection initiatives and agree that they should take actions in various tasks.

In reference to the respondents' evaluation of how importance the CSR activities contribute to the social practices in Table 4, it is able to see that even though these mean scores are all higher than the neutral point of 4 , they are less than the mean score range in Table 3. With the value from 5.23 (SP5) to highest 6.14 (SP2), the customers indicate that they believe CSR activities would bring more benefits to a destination' environment than the local community. Most of them appreciate the contribution of CSR to the conservation of culture, language, and heritage of the local people.

Table 4: The importance of CSR activities to a destination's social practices

\begin{tabular}{|l|c|c|}
\hline \multicolumn{1}{|c|}{$\begin{array}{c}\text { Social practices } \\
\text { (Cronbach's Alpha =0.920) }\end{array}$} & Mean & SD \\
\hline $\begin{array}{l}\text { SP1- Collaborate with social } \\
\text { and charity projects }\end{array}$ & 5.45 & 1.129 \\
\hline $\begin{array}{l}\text { SP2- Promotes local } \\
\text { community development and } \\
\text { heritage conservation }\end{array}$ & 6.14 & 0.877 \\
\hline $\begin{array}{l}\text { SP3- Promotes local } \\
\text { community development }\end{array}$ & 5.80 & 1.065 \\
\hline $\begin{array}{l}\text { SP4- Promote gender equality } \\
\text { in the employment practices }\end{array}$ & 5.54 & 1.279 \\
\hline $\begin{array}{l}\text { SP5- Encourage people of all } \\
\text { abilities to apply for jobs }\end{array}$ & 5.23 & 1.365 \\
\hline $\begin{array}{l}\text { SP6- Seek to balance work and } \\
\text { family life for your staff }\end{array}$ & 5.71 & 1.137 \\
\hline $\begin{array}{l}\text { SP7- Choose suppliers that } \\
\text { demonstrate their social } \\
\text { responsibility }\end{array}$ & 5.86 & 1.020 \\
\hline $\begin{array}{l}\text { SP8- Encourage customers to } \\
\text { contribute to social and charity } \\
\text { initiatives }\end{array}$ & 5.47 & 1.233 \\
\hline $\begin{array}{l}\text { SP9- Actively encourage } \\
\text { respect for the culture and } \\
\text { language of the area }\end{array}$ & 5.94 & 0.959 \\
\hline $\begin{array}{l}\text { SP10- Facilities are adapted for } \\
\text { disabled people }\end{array}$ & 6.06 & 1.003 \\
\hline $\begin{array}{l}\text { SP11- Promotes civic attitudes } \\
\text { among clients }\end{array}$ & 5.90 & 1.006 \\
\hline $\begin{array}{l}\text { SP12- Evaluates the social } \\
\text { impact of the business's CSR }\end{array}$ & 5.97 & 1.041 \\
\hline
\end{tabular}

The mean score range of the respondents' evaluation on how importance the CSR activities contribute to the local economy (Table 5) is the lowest among environmental, social, and economic practices, even though all the scores are above the neutral point of 4 . EC1 and EC2 got the lowest mean score of 5.12 and 5.13 respectively with largest standard deviation imply that there's a proportion of customers $(27.5 \%$ with EC1 and $34.1 \%$ with EC2) don't think it is necessary to recruit local staff wherever possible and they suspect the ability of CSR activities to give the staff a salary above 
the industry average. However, the customers highly value the contribution of CSR in conducting training programs for the staff and agree that they should consume more local product as a contribution to the local community where they visit. This finding coincides with Luu (2019) that training and mentoring programs under CSR activities to the tourism employees, especially frontline staff, will provide them with knowledge about customers and skills to serve customers beyond their role and recover service failures. Besides, tourism managers should encourage, appraise, and reward such service behaviours among frontline staff. Additionally, frontline staff should be trained to be appreciative to the empowerment that customers provide during service delivery as well as take advantage of it in reconfiguring tourism services.

Table 5: The importance of CSR activities to a destination's economic practices

\begin{tabular}{|l|c|c|}
\hline \multicolumn{1}{|c|}{$\begin{array}{c}\text { Economic practices } \\
\text { (Cronbach's Alpha=0.850) }\end{array}$} & Mean & SD \\
\hline $\begin{array}{l}\text { EC1- Choose local staff wherever } \\
\text { possible }\end{array}$ & 5.12 & 1.478 \\
\hline $\begin{array}{l}\text { EC2- Staff salaries are above } \\
\text { industry average }\end{array}$ & 5.13 & 1.357 \\
\hline $\begin{array}{l}\text { EC3- Has additional benefits for } \\
\text { their employees }\end{array}$ & 5.58 & 1.080 \\
\hline $\begin{array}{l}\text { EC4- Encourage customers to } \\
\text { consume/use local products }\end{array}$ & 5.80 & 1.021 \\
\hline $\begin{array}{l}\text { EC5- Encourage customers to } \\
\text { contribute to charitable activities }\end{array}$ & 5.20 & 1.119 \\
\hline $\begin{array}{l}\text { EC6- There are training programs } \\
\text { for the staff }\end{array}$ & 6.10 & 0.988 \\
\hline $\begin{array}{l}\text { EC7- Evaluates the economic } \\
\text { impact of the business's CSR }\end{array}$ & 5.88 & 1.107 \\
\hline
\end{tabular}

The above analysing reveals that customers not only care for tourism sustainable development, but also are willing to participate in tourism businesses' CSR activities to enhance the retain the environment, enhance culture and heritage of local community, contribute to the social development and local economy. Their cooperation would help the tourism stakeholders to achieve the CE goals. The respondents in this study showed that they are willing to participate in tourism businesses' CSR activities and they clearly realize their roles in $\mathrm{CE}$ development.

In Table 6, it is able to see that the respondents care the most for environmental issues and they are willing to participate in natural resources conservation activities and eager to tell their families and friends to do so. However, they are not confident in telling other tourists to participate in environmental protection $(32.91 \%)$, respect and conserve natural heritage $(27.22 \%)$, and save energy resources $(22.15 \%)$.
Table 6: Respondents' willingness to participate in CSR activities to contribute to CE development

\begin{tabular}{|c|c|c|}
\hline Item & $\mathbf{N}$ & Frequency \\
\hline I will reduce waste generation & 267 & $84.49 \%$ \\
\hline $\begin{array}{l}\text { I will tell my family and friends } \\
\text { to participate in environmental } \\
\text { protection }\end{array}$ & 257 & $81.33 \%$ \\
\hline $\begin{array}{l}\text { I will respect and conserve } \\
\text { natural heritage }\end{array}$ & 251 & $79.43 \%$ \\
\hline $\begin{array}{l}\text { I will try to use environmental- } \\
\text { friendly products }\end{array}$ & 223 & $70.57 \%$ \\
\hline $\begin{array}{l}\text { I will promote to my friends } \\
\text { and family any tourism } \\
\text { businesses or destination that } \\
\text { implement CSR activities }\end{array}$ & 205 & $64.87 \%$ \\
\hline $\begin{array}{l}\text { I will not consume wild- } \\
\text { animal-original products }\end{array}$ & 202 & $63.92 \%$ \\
\hline I will save domestic water & 201 & $63.61 \%$ \\
\hline $\begin{array}{l}\text { I will tell my family and friends } \\
\text { to save energy resources }\end{array}$ & 178 & $56.33 \%$ \\
\hline I will save energy resources & 177 & $56.01 \%$ \\
\hline $\begin{array}{l}\text { I will not buy or consume } \\
\text { products that use protected } \\
\text { natural resources }\end{array}$ & 173 & $54.75 \%$ \\
\hline $\begin{array}{l}\text { I will use local products where } \\
\text { I visit }\end{array}$ & 170 & $53.80 \%$ \\
\hline $\begin{array}{l}\text { I will respect and actively } \\
\text { participate in local cultural } \\
\text { activities }\end{array}$ & 159 & $50.32 \%$ \\
\hline $\begin{array}{l}\text { I will hire tourism services } \\
\text { from local people }\end{array}$ & 137 & $43.35 \%$ \\
\hline $\begin{array}{l}\text { I will choose a tourism business } \\
\text { or a tourism destination that use } \\
\text { renewable energy resources }\end{array}$ & 119 & $37.66 \%$ \\
\hline $\begin{array}{l}\text { I will tell other tourists to } \\
\text { participate in environmental } \\
\text { protection }\end{array}$ & 104 & $32.91 \%$ \\
\hline $\begin{array}{l}\text { I will contribute to local } \\
\text { community development at the } \\
\text { places I visit }\end{array}$ & 97 & $30.70 \%$ \\
\hline $\begin{array}{l}\text { I will contribute to tourism } \\
\text { landscape protection funds and } \\
\text { local community development } \\
\text { charities }\end{array}$ & 94 & $29.75 \%$ \\
\hline $\begin{array}{l}\text { I will tell other tourists to } \\
\text { respect and conserve natural } \\
\text { heritage }\end{array}$ & 86 & $27.22 \%$ \\
\hline $\begin{array}{l}\text { I will tell other tourists to save } \\
\text { energy resources }\end{array}$ & 70 & $22.15 \%$ \\
\hline
\end{tabular}

The respondents also understand their role in local community development as about half of them agree that they will "use local product" (53.8\%), "respect and actively participate in local cultural activities" (50.32\%), and "hire tourism services from local people" (43.35\%). That means they prefer to contribute to the local community through their travelling activities rather than directly contribute to a local fund or charity. 
Besides, the study found that there are significant differences in the attitude and behaviours of domestic tourists who are under 25 years old (or Gen Z) and other tourists in Vietnam. According to Andereck (2009), younger guests put a greater focus on responsible efforts than older people. However, in Table 7, respondents in this study express a reverse result. All items in the environmental practices (EP), except for EP2, get the pvalue $<0.05$ which mean there are significant differences among different groups of age. Young people under 25 years of age seem less believe that CSR activities would bring benefit to the environment conservation than the other senior groups.

Table 7: ANOVA tests for EP items among "Age" groups

\begin{tabular}{|l|r|r|}
\hline \multicolumn{1}{|c|}{ Items } & \multicolumn{2}{|c|}{ F value } \\
\hline EP1 & 4.13 & $\mathbf{0 . 0 0 3}$ \\
\hline EP2 & 2.10 & 0.081 \\
\hline EP3 & 4.24 & $\mathbf{0 . 0 0 2}$ \\
\hline EP4 & 3.42 & $\mathbf{0 . 0 0 9}$ \\
\hline EP5 & 2.43 & $\mathbf{0 . 0 4 8}$ \\
\hline EP6 & 6.55 & $\mathbf{0 . 0 0 0}$ \\
\hline EP7 & 6.86 & $\mathbf{0 . 0 0 0}$ \\
\hline EP8 & 3.08 & $\mathbf{0 . 0 1 6}$ \\
\hline EP9 & 4.78 & $\mathbf{0 . 0 0 1}$ \\
\hline EP10 & 6.41 & $\mathbf{0 . 0 0 0}$ \\
\hline EP11 & 4.43 & $\mathbf{0 . 0 0 2}$ \\
\hline EP12 & 4.00 & $\mathbf{0 . 0 0 4}$ \\
\hline EP13 & 2.69 & $\mathbf{0 . 0 3 1}$ \\
\hline EP14 & 10.12 & $\mathbf{0 . 0 0 0}$ \\
\hline
\end{tabular}

Table 8 indicates there are significant differences among different groups of age according to their attitude to the contribution of CSR to the society of the local community in a destination. In this study, the respondents under 25 years of age are less willing to collaborate with social and charity projects at the places they visit and less willing to promote the local community development and heritage conservation than other older groups. The people who show their high responsibility in cooperate with tourism businesses to respect the local people's culture, language, and heritage, together with encouraging the tourism businesses to create more jobs for local people and disabled people are over 55 years old.

Table 8: ANOVA tests for SP items among "Age" groups

\begin{tabular}{|c|r|r|}
\hline Items & F value & \multicolumn{1}{c|}{ Sig. } \\
\hline SP1 & 6.02 & $\mathbf{0 . 0 0 0}$ \\
\hline SP2 & 6.16 & $\mathbf{0 . 0 0 0}$ \\
\hline SP3 & 5.61 & $\mathbf{0 . 0 0 0}$ \\
\hline SP4 & 10.44 & $\mathbf{0 . 0 0 0}$ \\
\hline SP5 & 1.11 & 0.353 \\
\hline
\end{tabular}

\begin{tabular}{|l|l|l|}
\hline SP6 & 4.68 & $\mathbf{0 . 0 0 1}$ \\
\hline SP7 & 2.64 & $\mathbf{0 . 0 3 4}$ \\
\hline SP8 & 3.17 & $\mathbf{0 . 0 1 4}$ \\
\hline SP9 & 2.41 & $\mathbf{0 . 0 4 9}$ \\
\hline SP10 & 3.46 & $\mathbf{0 . 0 0 9}$ \\
\hline SP11 & 2.05 & 0.088 \\
\hline SP12 & 5.34 & $\mathbf{0 . 0 0 0}$ \\
\hline
\end{tabular}

According to another survey by The Nielsen Company (2012), younger consumers show a higher willingness to pay more for products and services from socially responsible companies as well as preferring socially responsible companies as workplace or investment opportunities.

However, this study reveals an opposite finding. As it is shown in Table 9, there are significant differences among different groups of age in their attitude towards the contribution of CSR to the $\mathrm{CE}$ of the local community. In all items, the people over 55 years old are the most willing ones to consume local products and contribute to charitable activities during their travelling. The senior people also want tourism businesses to evaluate their activities' impacts on the CE development of the local community and recruit local people wherever possible and pay them a high salary and benefits.

Table 9: ANOVA tests for SP items among "Age" groups

\begin{tabular}{|l|r|r|}
\hline Items & F value & \multicolumn{1}{c|}{ Sig. } \\
\hline EC1 & 9.40 & $\mathbf{0 . 0 0 0}$ \\
\hline EC2 & 17.13 & $\mathbf{0 . 0 0 0}$ \\
\hline EC3 & 11.38 & $\mathbf{0 . 0 0 0}$ \\
\hline EC4 & 3.47 & $\mathbf{0 . 0 0 9}$ \\
\hline EC5 & 6.76 & $\mathbf{0 . 0 0 0}$ \\
\hline EC6 & 2.98 & $\mathbf{0 . 0 2 0}$ \\
\hline EC7 & 2.14 & 0.075 \\
\hline
\end{tabular}

However, when running ANOVA tests for EP, SP, and EC items among "Job" groups, there is no significant differences between the attitude and behaviours of people who work in tourism/ travelling or related areas and who work in other areas (unrelated to tourism or travelling industries). 


\section{CONCLUSION}

This study focuses on identify the domestic tourism customers' attitude and behaviours towards tourism/ travelling and tourism/travelling-related businesses' CSR activities and their perceptions on how these activities can contribute to the circular economy development in the Vietnamese tourism destinations.

It is found that domestic customers in this study are aware of the benefits of CSR activities in sustainable tourism, especially in environment practices. They try to save natural resources (energy, water, etc.), use renewable energy sources where is relevant, consume organic and environmentally friendly products, reduce using plastic, use recycle products, and do more recycling. They believe that CSR would be a long-term strategy of tourism businesses to enhance their brand image and competitive advantages. Vietnamese customers are willing to cooperate with tourism businesses in CSR activities. However, young tourists seem show less confidence in the contribution of CSR into $\mathrm{CE}$ development and sustainability than senior people. Therefore, people under 25 years old are less willing to participate in the CSR activities of tourism businesses. The people over 55 years of age in Vietnam are those who are willing to pay more and consume more local products, collaborate with social activities and charity projects, promote the local community's values, and contribute to the local economy, besides other environment conservation activities. This finding is reverse to some previous studies in other countries (EU and Australia).

The study reveals that job and travelling habit do not affect the customer's attitude and behaviours towards CSR's contribution to the CE development. People who don't work in tourism or tourism-related areas have the similar perception, attitude, and behaviours towards CSR like those who work in tourism industry. And people who travel one to two times per year also share the same view and cooperative mind in CSR activities like those who travel regularly. Besides, the COVID-19 has stopped many people enjoying their travelling, however, their attitude towards tourism businesses' CSR keeps unchanged. They believe that CSR activities will contribute highly to the circular economy in all three dimensions: environment, society, and economy.

However, as the study finds there are significant differences among the attitude and behaviours of different group of age, especially in young tourists under 25 , this study suggests Vietnamese local governments and tourism businesses should focus more on educate young Vietnamese customers during their visits to a tourism destination about the benefits of CSR and customer's cooperation in CSR activities.

A limitation of this study is that the data were collected at a single time point, in which case dynamic issues such as how different dimensions of tourists' attitude and behaviours of tourism businesses' CSR and its contribution to $\mathrm{CE}$ development may change over time are ignored. Therefore, future research would focus more on tourists' behavioural changes in this issue over time and identify the impact factors that lead to the differences between the behaviours of Gen $\mathrm{Z}$ and other tourists towards CE development in Vietnam.

\section{REFERENCES}

[1] Adongo, R., Choe, J. Y., \& Han, H. (2017). Tourism in Hoi An, Vietnam: Impacts, perceived benefits, community attachment and support for tourism development. International Journal of Tourism Sciences, 17(2), 86-106.

[2] Aguinis, H. (2011). Organizational responsibility: Doing good and doing well.

[3] Albus, H., \& Ro, H. (2017). Corporate social responsibility: The effect of green practices in a service recovery. Journal of Hospitality \& Tourism Research, 41(1), 41-65.

[4] Alonso-Almeida, M. D. M., Rodríguez-Antón, J. M., \& Rubio-Andrada, L. (2012). Reasons for implementing certified quality systems and impact on performance: an analysis of the hotel industry. The Service Industries Journal, 32(6), 919-936.

[5] Andereck, K. L. (2009). Tourists' perceptions of environmentally responsible innovations at tourism businesses. Journal of sustainable tourism, 17(4), 489499.

[6] Ayuso, S. (2006). Adoption of voluntary environmental tools for sustainable tourism: Analysing the experience of Spanish hotels. Corporate social responsibility and environmental management, 13(4), 207-220.

[7] Becker-Olsen, K. L., Cudmore, B. A., \& Hill, R. P. (2006). The impact of perceived corporate social responsibility on consumer behavior. Journal of business research, 59(1), 46-53.

[8] Bohdanowicz, P., \& Zientara, P. (2009). Hotel companies' contribution to improving the quality of life of local communities and the well-being of their employees. Tourism and Hospitality Research, 9(2), 147158 .

[9] Byrd, E. T., Bosley, H. E., \& Dronberger, M. G. (2009). Comparisons of stakeholder perceptions of tourism impacts in rural eastern North Carolina. Tourism Management, 30(5), 693-703.

[10] Carroll, A. B. (1991). The pyramid of corporate social responsibility: Toward the moral management of organizational stakeholders. Business horizons, 34(4), 3948.

[11] Cha, M. K., Yi, Y., \& Bagozzi, R. P. (2016). Effects of customer participation in corporate social responsibility (CSR) programs on the CSR-brand fit and brand loyalty. Cornell Hospitality Quarterly, 57(3), 235-249.

[12] Chafe, Z., \& Honey, M. (2005). Consumer demand and operator support for socially and environmentally 
responsible tourism. Center on Ecotourism and Sustainable Development.

[13] Dong, H., Li, P., Feng, Z., Yang, Y., You, Z., \& Li, Q. (2019). Natural capital utilization on an international tourism island based on a three-dimensional ecological footprint model: A case study of Hainan Province, China. Ecological Indicators, 104, 479-488.

[14] El-Kassar, A. N., \& Singh, S. K. (2019). Green innovation and organizational performance: the influence of big data and the moderating role of management commitment and HR practices. Technological Forecasting and Social Change, 144, 483-498.

[15] Fatma, M., Rahman, Z., \& Khan, I. (2016). Measuring consumer perception of CSR in tourism industry: Scale development and validation. Journal of Hospitality and Tourism Management, 27, 39-48.

[16] Freeman R.E (1984). Strategic management: A stakeholder approach. Pittman Publishing, Marshfield, MA

[17] Gursoy, D., Jurowski, C., \& Uysal, M. (2002). Resident attitudes: A structural modeling approach. Annals of tourism research, 29(1), 79-105.

[18] Ellen MacArthur Foundation. (2021). The circular economy in detail. https://www.ellenmacarthurfoundation.org/explore/thecircular-economy-indetail\#: : text=A\%20 circular\%20economy\%20is\%20a,the $\% 20$ consumption\%20of\%20finite\%20resources. (Accessed on 16 Aug 2021)

[19] Font, X., Walmsley, A., Cogotti, S., McCombes, L., \& Häusler, N. (2012). Corporate social responsibility: The disclosure-performance Management, 33(6), 1544-1553.

gap. Tourism

[20] Girard, L. F., \& Nocca, F. (2017). From linear to circular tourism. Aestimum, 70.

[21] Ritchie, J. R., Goeldner, C. R., \& McIntosh, R. W. (2003). Tourism: principles, practices, philosophies. John Wiley \& Son (New Jersey).

[22] Hall, C. M. (2009). Degrowing tourism: Décroissance, sustainable consumption and steady-state tourism. Anatolia, 20(1), 46-61.

[23] Michael Hall, C., \& Saarinen, J. (2021). 20 Years of Nordic climate change crisis and tourism research: a review and future research agenda. Scandinavian Journal of Hospitality and Tourism, 21(1), 102-110.

[24] Ham, S., \& Han, H. (2013). Role of perceived fit with hotels' green practices in the formation of customer loyalty: Impact of environmental concerns. Asia Pacific Journal of Tourism Research, 18(7), 731-748.

[25] Han, S., Li, G., Lubrano, M., \& Xun, Z. (2020). Lie of the weak: Inconsistent corporate social responsibility activities of Chinese zombie firms. Journal of Cleaner Production, 253, 119858 .

[26] Holcomb, J. L., Upchurch, R. S., \& Okumus, F. (2007), Corporate social responsibility: what are top hotel companies reporting?. International journal of contemporary hospitality management.
[27] Jensen, Ø., \& Prebensen, N. (2015). Innovation and value creation in experience-based tourism.

[28] Karani, A. P., \& Day, J. G. (2011). Corporate social responsibility and employee recruiting in the tourism industry.

[29] Kasim, A. (2007). Towards a wider adoption of environmental responsibility in the hotel sector. International journal of hospitality \& tourism administration, 8(2), 25-49.

[30] Lee S., Park H., Kim K. H., \& Lee C. K. (2021), A moderator of destination social responsibility for tourists' pro-environmental behaviors in the VIP model, Journal of Destination Marketing and Management, Vol 20. ISSN 2212-571X

[31] Lee C. K., Olya H., Ahmad M. S., Kim K, H., \& Oh M. J. (2021), Sustainable intelligence, destination social responsibility, and pro-environmental behaviour od visitors: Evidence from an eco-tourism site, Journal of Hospitality and Tourism Management, Vol 47, pp 365376

[32] Luu, T. T. (2018). Employees' green recovery performance: the roles of green HR practices and serving culture. Journal of Sustainable Tourism, 26(8), 13081324.

[33] Luu, T. T. (2019). CSR and customer value co-creation behavior: The moderation mechanisms of servant leadership and relationship marketing orientation. Journal of Business Ethics, 155(2), 379-398.

[34] Manniche, J., Topsø Larsen, K., Brandt Broegaard, R., \& Holland, E. (2017). Destination: A circular tourism economy: A handbook for transitioning toward a circular economy within the tourism and hospitality sectors in the South Baltic Region

[35] Martínez, P., \& Del Bosque, I. R. (2013). CSR and customer loyalty: The roles of trust, customer identification with the company and satisfaction. International Journal of Hospitality Management, 35, 89-99.

[36] Nunkoo, R., Gursoy, D., \& Juwaheer, T. D. (2010). Island residents' identities and their support for tourism: an integration of two theories. Journal of Sustainable Tourism, 18(5), 675-693.

[37] Oreve L., (2015). Circular Tourism. https://www.circularcityfundingguide.eu/circularsector/tourism/ (Accessed on 20 Aug 2021)

[38] Prebensen, N. K., Vitters $\varnothing$, J., \& Dahl, T. I. (2013). Value co-creation significance of tourist resources. Annals of tourism Research, 42, 240-261.

[39] Prud'homme, B., \& Raymond, L. (2013). Sustainable development practices in the hospitality industry: An empirical study of their impact on customer satisfaction and intentions. International Journal of Hospitality Management, 34, 116-126.

[40] Raub, S., \& Blunschi, S. (2013). The power of meaningful work: How awareness of CSR initiatives fosters task significance and positive work outcomes in service employees. Cornell Hospitality Quarterly, 55(1), 10-18. 
[41] Reisinger, A. SOCIAL RESPONSIBILITY AND TERRITORIAL DEVELOPMENT.Cohesion and Development Policy in Europe, 99.

[42] Rodríguez, F. J. G., \& Cruz, Y. D. M. A. (2007). Relation between social-environmental responsibility and performance in hotel firms. International Journal of Hospitality Management, 26(4), 824-839.

[43] Rhou, Y., Singal, M., \& Koh, Y. (2016). CSR and financial performance: The role of CSR awareness in the restaurant industry. International Journal of Hospitality Management, 57, 30-39.

[44] Su, W., Peng, M. W., Tan, W., \& Cheung, Y. L. (2016). The signaling effect of corporate social responsibility in emerging economies. Journal of business Ethics, 134(3), 479-491.

[45] Su, L., Huang, S., van der Veen, R., \& Chen, X. (2014). Corporate social responsibility, corporate reputation, customer emotions and behavioral intentions: A structural equation modeling analysis. Journal of China Tourism Research, 10(4), 511-529.

[46] Su, L., \& Swanson, S. R. (2017). The effect of destination social responsibility on tourist environmentally responsible behavior: Compared analysis of first-time and repeat tourists. Tourism Management, 60, 308-321.

[47] Schumann F. (2020), Circular economy principles and small island tourism: Guam's initiatives to transform from linear tourism to circular tourism, Journal of Global Tourism Research, Vol. 5(1)

[48] Stanford, D. (2008). 'Exceptional visitors': Dimensions of tourist responsibility in the context of New Zealand. Journal of Sustainable Tourism, 16(3), 258-275.

[49] Tamajón, L. G., \& Font, X. (2013). Corporate social responsibility in tourism small and medium enterprises evidence from Europe and Latin America. Tourism Management Perspectives, 7, 38-46.

[50] The Nielsen Company (2012). Nielsen Identifies Attributes of the Global, Socially-conscious Consumer
$2012 . \quad$ https://ir.nielsen.com/news-events/pressreleases/news-details/2012/nielsen-identifies-attributesof-the-global-socially-conscious-consumer/default.aspx (Accessed on 20 August 2021).

[51] Tuan, A., \& Moretti, A. (2017). Engaging consumers on social media: empirical evidence from the communications analysis of a CSR oriented company. International Journal of Technology Marketing, 12(2), 180-205.

[52] Tran, H. A. T., Hwang, Y. S., Yu, C., \& Yoo, S. J. (2018). The effect of destination social responsibility on tourists' satisfaction: The mediating role of emotions. Sustainability, 10(9), 3044.

[53] UNWTO, 2008. UNWTO Tourism Highlights, 2008 Edition. https://www.e-unwto.org/doi/pdf. (Accessed on 18 Aug 2021)

[54] Vargas-Sánchez, A. (2018). The unavoidable disruption of the circular economy in tourism. Worldwide Hospitality and Tourism Themes.

[55] Winter, T., Teo, P., \& Chang, T. C. (Eds.). (2008). Asia on tour: Exploring the rise of Asian tourism. Routledge.

[56] Xu, S., Qiao, M., Che, B., \& Tong, P. (2019). Regional anti-corruption and CSR disclosure in a transition economy: the contingent effects of ownership and political connection. Sustainability, 11(9), 2499

[57] Yi, Y., \& Gong, T. (2013). Customer value co-creation behavior: Scale development and validation. Journal of Business research, 66(9), 1279-1284.

[58] Yu, C., \& Hwang, Y. S. (2019). Do the social responsibility efforts of the destination affect the loyalty of tourists?. Sustainability, 11(7), 1998.

[59] Zorpas, A. A, Voukkali, I., Chatziparaskeva, G., NavarroPedreño, J., \& Loizia, P., (2021). Measuring the level of environmental performance on coastal environment before and during the COVID-19 pandemic: a case study from Cyprus. Sustainability, 13(5), 2485 